International Journal of Library \& Information Science (IJLIS)

Volume 8, Issue 2, May-August 2019, pp. 51-64, Article ID: IJLIS_08_02_006

Available online at

http://iaeme.com/Home/issue/IJLIS?Volume=8\&Issue2

Journal Impact Factor (2019): 9.8614 (Calculated by GISI) www.jifactor.com

ISSN Print: 2277-3533 and ISSN Online: 2277-3584

C IAEME Publication

\title{
EFFECTS OF FEE-BASED SERVICES ON LIBRARY SERVICE DELIVERY IN FEDERAL UNIVERSITY LIBRARIES IN NIGERIA: A STUDY OF MICHAEL OKPARA UNIVERSITY OF AGRICULTURE, UMUDIKE, ABIA STATE, NIGERIA
}

\author{
Juliana O. Akidi, $P h D, C L N$ \\ University Library \\ Michael Okpara University of Agriculture, Umudike \\ Abia State, Nigeria \\ Chukwuemeka Chukwueke \\ Department of Library and Information Science \\ Michael Okpara University of Agriculture, Umudike \\ Abia State, Nigeria.
}

\begin{abstract}
The study investigated the effects of fee-based services on library service delivery in federal university libraries using the Michael Okpara University of Agriculture Library, Umudike as a focal point. The study was guided by four (4) research objectives. It adopted a survey design with a population of fifty-three (53) library staff from the university. The complete census sampling technique was adopted which implies the use of the entire population as respondents. A checklist and researchermade questionnaire were the instruments for data collection. Hence, fifty-three copies of the questionnaire were administered to the respondents. All the copies administered were retrieved giving a response rate of 100\%. Data was analyzed using simple percentages, frequency counts, and mean scores, as well as presented in frequency tables. Furthermore, a criterion mean of 2.50 was adopted to ascertain the level of agreement or disagreement of item statements. The study found out that the library studied adopted few fee-based services, more of free-based services, and total absence of some of the library services investigated. The study revealed that although only few fee-based library services were adopted, it has numerous effects on the federal university library such as generation of additional income, increases library services, goodwill and patronage among other numerous positive effects. The study also found out challenges of poor planning/pricing policy, absence of quality services, and gross
\end{abstract}


resistance of the concept of fee-based services as among the challenges facing feebased library services and its effectiveness in federal university libraries. Based on the findings, the study recommends efforts to make the prices for fee-based services affordable, strong relationship between the library and its users, provision of relevant library services and introduction of digitized services as means to further strengthen fee-based library services and make it effective in federal university libraries, in order to engender the desired delivery.

Key words: Effects, Fee-based, Delivery, Library Services, University Libraries

Cite this Article: Juliana O. Akidi and Chukwuemeka Chukwueke, Effects of FeeBased Services on Library Service Delivery in Federal University Libraries in Nigeria: A Study of Michael Okpara University of Agriculture, Umudike, Abia State, Nigeria, International Journal of Library \& Information Science, 8(2), 2019, pp. 51-64. http://iaeme.com/Home/issue/IJLIS?Volume=8\&Issue2

\section{INTRODUCTION}

The issue of library services delivery has been of a major concern in libraries of the digital age. This is as a result of questioning the relevancy of libraries in the digital age when almost all information can be gotten without physically visiting the four-walls of the library. One thing such group of persons asking these questions failed to understand is the fact that libraries are no longer only found in the building as they have occupied most of the cloud spaces one can imagine. It is important to remember that the library is not just a mere building but includes the collection of sources of information made accessible to a defined community of users for reading, research or borrowing purposes. It may be a physical building, a virtual space or room that provides physical and digital access to information materials. Ifidon (2012) believes that the library plays vital roles in the processes of teaching, learning, research and community development. These multifaceted roles of the library bring about societal, economic and national development, promote scholarship, foster social inclusion and cohesions, promotes concepts of civic centers and community services, and encourages working relationships among democratic institutions, advancement of cooperation and understanding, among other things (Chukwueke, Onuoha \& Nnadozie, 2018). The library, through the provision of diverse services still remains the cornerstone of civil society, and of the liberal democracy we have come to cherish. This invariably means that no nation or institution can survive without library.

Libraries in most developing nations are facing poor-funding of their programs and services. The federal university libraries are not exclusive of this although they are expected to enjoy $10 \%$ of the annual budget of the parent institution as recommended by the National University Commissions (NUC) and the annual grants/assistance from the Tertiary Education Trust Fund (TETFUND) (Nnadozie, 2013). If truly these federal university libraries in Nigeria have all these funds at their disposal, what is then hindering the effectiveness and efficiency of most of their programs and services delivery compared to their counterparts in the developed nations? It could be unarguably agreed that $95 \%$ of Nigerian university libraries, especially the federal-owned are not effectively delivering all the services required of them because of relegation and total negligence by their parent institutions in respect of funds available to them for such services delivery. Regrettably, Dibu (as cited in Nnadozie, 2013) observes that the relegation of these university libraries in recent decades is indeed a matter of great concern as it has not only affected the fund available to the libraries, but could be perceived in the areas of inadequacy of materials acquired, poor services rendered and low level of satisfaction derived by the users. 
Consequently, poor funding and absence of additional means of income generation in most federal university libraries have resulted in scanty library shelves, and where the shelves are stocked, the nature of materials and service delivered, coupled with lack of innovations in such libraries. The question therefore is whether the management of these federal university libraries is to fold their hands and watch their patrons disappear in this digital age, the library building collapse and the librarians suffer undue hardship in a bid to provide services to the remnant of the users and remain relevant in information delivery. There is therefore urgent call for library managers to carefully review the state of funding of federal university libraries in Nigeria. Thus, in an effort to still provide relevant and effective library services in our federal universities libraries, management of university libraries must not allow themselves to crumble into disuse but must seek avenues to boost their revenue and income generation. The expectations of users on libraries should be a motivating factor to make these libraries face the challenges confronting them as they are expected to deliver absolutely fundamental services, which should positively affect the university community. These fundamental services expected of the library, whether on free or fee-based serve as the anchor, which holds the existence of the library without which, the library would go into extinction and cease to function as a centre for teaching, learning and research.

Among these library services expected of the federal university libraries are loan (book), reference/referral, information packaging and repackaging, current awareness, indexing and abstracting, documentation, bindery and reprographic, inter-library loan, document delivery, literature search, scholarly database search, and retrieval, book reservation, library orientation, and Internet services, among other services (Okiy, 2005; Ifidon, 2012; Ilo, Idaerefama \& Fufuri, 2016; Chukwueke, Onuoha \& Nnadozie, 2018). Nonetheless, apart from the general routine services provided by the library to her users, there exist arrays of specialized services through which the library can raise funds (Okiy, 2005). As outlined in Ilo, Idaerefama and Fufuri (2016), these services include, but not limited to: Internet browsing services, repackaging of information, sale of old stocks/weeded materials, hiring of library space, reprographic services (photocopying, printing and translational services), consultancy, registration and clearance of users, selective dissemination of information, current awareness services, document delivery, bindery services, literature search, indexing and abstracting services, amongst other services

Having reviewed the problem and state of most federal university libraries and some ways to ameliorate it, according to some literature, the big question remains if fundamental services are provided by Michael Okpara University of Agriculture, Umudike Library. If they are provided, what is the extent of provision, are they free-based or fee-based? If they are feebased, what are the effects of these fee-based services on the strength and opportunity of services delivered, and finally what are the challenges facing fee-based library services in Michael Okpara University of Agriculture, Umudike. This is the focus of this study as the crux of this work is to investigate the effects of fee-based services in the delivery of library services in federal university libraries in Nigeria.

\section{PURPOSE OF THE STUDY}

The primary purpose of this study is to investigate the effects of fee-based services on delivery of library services in federal university libraries in Nigeria. Specifically, the objectives are as follows; to:

- find out the status of library services offered in MOUAU Library;

- determine the effects of fee-based services in MOUAU Library;

- ascertain the challenges facing fee-based services in MOUAU Library; and 
- $\quad$ suggest strategies to enhance effective fee-based services in MOUAU Library

\section{REVIEW OF RELATED LITERATURE}

The emergence of ICT, according to Ilo, Idaerefama and Fufuri (2016) has created an avenue through which funds can be raised in university libraries. One of such avenues is the Internet browsing services and digitization. The authors are of the view that the university library management can equip its ICT unit with Internet facilities and charge a token from users who visit the unit to have access to online information resources and services. On repackaging of information as a fee-based service, Oguntuase and Falaiye (2004) opine that information repackaging, which involves expert evaluation, careful/systematic retrieval and analysis of information in order to ensure accuracy and currency as well as interpreting it to serve a particular user group, can be marketed by university libraries. This the library can do by selecting and organising information contents with a view of satisfying the needs of a selected group of users.

Fee-based library services refer to services and products rendered by the library to her clienteles in exchange for financial benefits. Webb (2003) states that fee-based services are ranges of information services provided on demand and in return for payment. In addition, Reitz (2004) defines fee-based services as services provided by the library or information brokers in exchange of monetary payments. As noted by Anyaoku (2012), the issue of charging fees for library services and information products has been a subject of debate amongst information professionals. This debate however takes leap from the fact that the provision of information services in libraries should be free (Yetunde, 2008). This is based on the fact that the library is a non-profit organization (Ubogu \& Okiy, 2011). Notwithstanding, it is clear that most university libraries, especially in Nigeria and other developing nations are instituting fees on some services offered, as a means of generating revenue and additional income to augment the meagre annual disbursement they receive from their parent institutions (Nnadozie, 2013; Ward, Fong \& Camille, 2002). In addition, these fee-based services can effectively serve as a way of meeting the existing needs of library users and delivering new/modern library services (Jenda, 2000). Further corroborating the view of Jenda (2000), Obodoeze (2007) opines that fee-based services would make the library users appreciate the services rendered by library, for it is quite relative that cost entails value. Consequently, the idea behind any fee-based service in the library lies in the fact that for the library to engender users to give out their money in exchange for certain services received, it must be creative enough to improve on the existing and also to introduce new varieties in line with the needs of its active and potential users, such that would endear them to willing pay (Obodoeze, 2007). Hence, fee-based services in university libraries ensures that the librarian and the library staff at all times, come up with creative and innovative strategies in the area of service and product creation and customization, which will go a long way to attract as well as retain patronage even at a cost.

According to Anyaoku, (2012), the recent decline in funds to libraries and the change in the concept of information from a free resource to a marketable resource in the information age have necessitated the re-evaluation of free services in the libraries. However, Nnadozie (2013) asserts that the resultant underfunding of the libraries has become perennial and may remain so if the national economy does not improve significantly. It must be pointed out that university libraries have not been isolated from the financial problems of their parent bodies. As such the university libraries are handicapped in their role of promoting scholarship and reading culture in their parent institutions. Commenting on the debate for and against fee based library services, Ekoja (1996) points out that those who are arguing for fee-based library services are winning the debate because of many compounding variables, which have 
made it expedient for libraries around the world to look outside their traditional sources of funding in order to raise additional funds to be able to sustain the level of services which hitherto, was not adequately taken care of through normal funding.

Furthermore, the paradigm shift to electronic information resources has made library patrons to seek information in varied formats, which requires additional cost to deliver them (Ishola, 2014). As such, the multi-diverse needs of library users, coupled with minimal funds at the disposal of these libraries, necessitates devising alternative means to generate revenue in order to meet such increasing needs of its users. It is therefore in line with the aforementioned that libraries, and particularly, university libraries have ventured into imposing fees on certain services it renders to its users (Yetunde, 2008). Ishiola (2014) study on funding problems in Nigerian university libraries: fee-based library and information services to the rescue, focus on pricing policy, revealed that university administration normally releases funds though in small quota to libraries, and that students pay to access and use the library services in the following areas: registration fees, inter-library loan services, online services, Internet connectivity, CD-ROM services, reprographic services, etc. Furthermore, Igbokwe, Ezeji and Obidike (2010) study on problems militating against marketing of library services in selected Nigerian libraries revealed that the major fee-based services were binding and photocopy while the free services were compilation of bibliography and retrospective services. This is because fee-based services not only ensure additional income generation but goes further to indirectly improve the services of the library as well as increase its ability to procure the relevant facilities and in so doing improve users satisfaction (Nnadozie, 2013; Jenda, 2000, Obodoeze, 2007; Ward, Fong \& Camille, 2002). Furthermore, Anyaoku (2009) believes that fee-based services have been advocated and accepted as the panacea to the economic depression in libraries. Hence, some libraries have introduced different courses of actions to promote income generation from library patrons. Not minding the massive cry of most university libraries in respect to poor funding as well as the massive campaign by scholars, some of these libraries in Nigeria have not totally delved into the concept of fee-based services (Olurotimi, 2014).

Despite contending arguments about the rational and after-effect of imposing fees on library services, the inherent benefits of these fee-based services to the library give it an ample advantage. These advantages as opined by Mahmood and Haider (2005) include meeting the increasing needs of users, effective and efficient utilization of library resources and services, maintenance and upgrade of library facilities and resources, and creation of new ideas. According to Mahmood and Haider (2005), fee-based library services limit and prevent wastage and reduces the burden on the use of library resources and services. Stating further, the authors assert that people are already used to paying for such services at parks, museums etc., how much more information? People tend to value what they pay for and as such, it improves the value of the resources or services so provided or rendered. This becomes even more in-tune with the fact that the service given will be of immense benefits to the user. Information seeking will hence be matter of necessity as against taking a stroll in the library. The bane of this argument is that fee-based services reduce abuse and enhance effective and efficient use and management of resources and services. Furthermore, Anyaoku (2012) believes that the more funds available to the library, the better its ability to improve on its services and facilities. Anyaoku (2012) has it that fee-based services strengthen the opportunities for research and technical assistance rendered. In addition, it enhances access to electronic and print materials/collections, while also creating avenues for open access and availability. Nwosu (as cited in Ishola, 2014) is of the opinion that even though libraries have traditionally been custodians of information which are provided free of charge to users, the recent decline and under funding of libraries and the change in the concept of information 
from a free resource to a marketable resource in the information age have necessitated the revaluation of free services in libraries.

Studies and investigations have shown that most university libraries in Nigeria still operate within the range of charging fees for users' registration, levies for over-due fines, charges for photocopying and charges for database searching (Obodoeze, 2007). Despite the limitation in library services being charged, Ifidon, in Anyaoku (2012) states that the existing fee-based library and information services in Nigerian libraries, especially, the federal university libraries are not properly managed. Stating further, Ifidon explains that the library staff offers fee-based services routinely like every other library service and the records of the transactions are not well maintained either in such a way as to assist management in effective decision making processes or make for adequate funding of these libraries. Nonetheless, it is not even easy for Nigerian federal university libraries to emback on fee-based services. This is because the dwindling finances/financial crisis have ultimately led to the inability of the university libraries to sustain their services and even institute new programme like e-current awareness services, e-SDI services, mobile phone services and other special services in their libraries. The issue of poor planning and pricing policy is another challenge (Anyaoku, 2012). This therefore calls for adequate planning from the onset of fee-based services in the libraries, especially federal university libraries.

Retrospective conversion and digitization of information resources guarantees prompt/easy access and retrieval of information from wherever and whenever. Hence, automation of library activities will go a long way to enhance service delivery by federal university libraries and also engender fee-based services of the library. Igyuve and Ashaver (as cited in Ishola, 2014) study revealed that fee-based services have positively impacted on university libraries in Makurdi Metropolis. The study therefore recommended that university libraries have to survive by introducing more fee-based library services to generate extra funds for the up-keep and survival of university libraries. Ahenkorah-Marfo and Osei-Boadu (2013) study on fee-based services as a source of funding for university libraries in Ghana revealed that the majority of the respondents $(83 \%)$ agreed to the fact that packaging of information for a fee is a viable option for libraries to generate income internally. The study further recommended that public universities should take advantage of this potentially viable means of income generation and push for a paradigm shift through their library committees

The inability of library management to effectively outline lay down plans on what services should be charged for, the bases for which such charges should be made, and the pricing policies is a big hindrance to the success of fee-based services in libraries. Corroborating this, Komolafe-Opadeji and Yacob (as cited in Okek, Urhiewhu \& Nwafor, 2015) stated that many university libraries especially those in Nigeria are uncomfortable pricing library services and could not comfortably strike a balance between the traditional library ethics of public use and the need for users to pay for services being rendered to them. Most librarians and information scholars are still not convinced about the morality behind fee-based library services. There is also the issue of the inability of library management to effectively market and show-case its services and products, as Nnadozie (2013) emphasized that people will only patronize a service or a product if they knew about it. Thus, poor marketing skills and strategies have been a major problem in libraries as most librarians do not understand the concept in library practices, as they see themselves as service providers in a non-profit making organisation like the library. As a result, the necessary cordial relationship that should exist between the library and its users is savaged. Others involve funding issues, user dissatisfaction, absence of skills and expertise on the side of the librarian, and user perceptions contribute to the challenges of fee-based services in libraries (Ishola, 2014; Ifidon, 2005). Igbokwe, Ezeji and Obidike (2010) found out poor allocation of fund and inefficient technology as problems that hinder 
effective marketing and fee-based library services. Recommendations however, came in the area of increasing the level of user satisfaction which will invariably guarantee increased patronage.

Being an emerging trend in most developing nations such as Nigeria, to make it effective and more efficient, implementation of fee-based services in Nigerian federal university libraries requires a conscious plan of action, which will enable the librarians to better understand through a feasible study, what it takes to start (Okeke, Urhiewhu \& Nwafor, 2015). Also, library staff should be trained on the modalities involved in fee-based services. In addition, there is need for formulation of policies that would stipulate the services to be charged, at what price, and how the prices are to be fixed (Ishola, 2014). A well laid plan of action should stipulate target and procedures for achieving it. It is also pertinent to understand that marketing is all about creating awareness on the existence of certain specialized and personalized services and products of the library (Nnadozie, 2013). This entails bringing to the fore, knowledge about the existence of certain services which hitherto were unknown to the library users. Through marketing, users get to see what the library holds in stock, which and this will further endear them into seeking such services. Marketing also creates an environment for friendly interaction between the library and its users thus fostering a platform for cordial relationship. In so doing, users can easily relay their needs and also get expert advice even at the expense of a fee.

\section{METHODOLOGY}

Descriptive survey research design was used for the study. The population of the study was fifty-three (53) library staff of Michael Okpara University of Agriculture, Umudike, which comprises of thirteen (13) professional librarians, sixteen (18) para-professionals and twentytwo (22) support staff. Consequently, the study adopted a complete census sampling technique, since there was no need to sample as the population was manageable. The instruments used for data collection were a checklist and a researcher-structured questionnaire. The checklist was used to record the status of library services offered in MOUAU Library. The researcher-structured questionnaire was titled "Effects of Fee-Based Services on Library Service Delivery Questionnaire" (EFBSLSDQ). The structured questionnaire was used to guarantee anonymity and unbiased responses and also structured to facilitate the collection of data needed from the library staff. The questionnaire was divided into two (2) sections (A and B). Section A was designed to collect demographic data of the respondents (library staff), while section B was built on a four (4)-point scale and divided into four (3) clusters which focused on the research objectives 2,3 , and 4 . It was made up of twenty-three (23) item statements. Furthermore, the instruments were validated by three (3) expects drawn from Measurement and Evaluation, College of Education, practicing librarian in the university library, and a lecturer in the Department of Library and Information Science; all in Michael Okpara University of Agriculture, Umudike. The questionnaire was also subjected to reliability test and scored a coefficient value (r) of .81. Furthermore, the researchers distributed the questionnaire to the targeted respondents and recovered all at the end of one week, given a response rate of $100 \%$. Data collected was analyzed using frequency counts and mean ratings. The four-point-scale method was the parameter used to determine the degree of agreement and/or variance in each item of the questionnaire. Meanwhile, the criteria mean of 2.50 was used in reaching a decision on whether to accept the response as positive or reject, as the case may be. Thus, items with a mean score of 2.50 and above were accepted while items with mean score of less than 2.50 were rejected. 
Juliana O. Akidi and Chukwuemeka Chukwueke

\section{RESULTS AND DISCUSSION OF FINDINGS}

The data generated was analysed and presented in tables

Table 1 Demographic Variables of Respondents

\begin{tabular}{|ll|c|c|}
\hline \multicolumn{2}{|c|}{ Category } & Frequency & Percentage \\
\hline Gender: & Male & 15 & 28.3 \\
& Female & 38 & 71.7 \\
\hline Status: & Professional & 13 & 24.5 \\
& Para-professional & 18 & 34.0 \\
& Support staff & 22 & 41.5 \\
\hline
\end{tabular}

The table above presents the demographic variables of the respondents. Analysis shows that both gender (male and female) were represented in the sample. However, the respondents constitutes of $15(28.3 \%)$ of male staff and $38(71.7 \%)$ female staff. Furthermore, the various categories of staff of the library were represented. They include $13(24.5 \%)$ professional library staff, $18(34.0 \%)$ para-professionals and $22(41.5 \%)$ support staff of the library.

Table 2 Status of Library Services Offered in MOUAU

\begin{tabular}{llccc}
\hline S/n & \multicolumn{1}{c}{ Library Services } & Fee-based & Free-based & Not provided \\
\hline 1 & Internet browsing & $\sqrt{ }$ & $\mathrm{X}$ & $\mathrm{X}$ \\
2 & e-Selective Dissemination of Information & $\mathrm{X}$ & $\mathrm{X}$ & $\sqrt{ }$ \\
3 & Mobile phone services & $\mathrm{X}$ & $\mathrm{X}$ & $\sqrt{ }$ \\
4 & e-Current awareness service & $\mathrm{X}$ & $\mathrm{X}$ & $\sqrt{ }$ \\
5 & Manual Current Awareness Services & $\mathrm{X}$ & $\sqrt{ }$ & $\mathrm{X}$ \\
6 & Indexing & $\mathrm{X}$ & $\sqrt{ }$ & $\mathrm{X}$ \\
7 & Charging and discharging services, & $\mathrm{X}$ & $\sqrt{ }$ & $\mathrm{X}$ \\
8 & Abstracting services, & $\mathrm{X}$ & $\mathrm{X}$ & $\sqrt{ }$ \\
9 & Compilation of bibliographies/reading list & $\mathrm{X}$ & $\sqrt{ }$ & $\mathrm{X}$ \\
10 & Binding services & $\sqrt{ }$ & $\mathrm{X}$ & $\mathrm{X}$ \\
11 & Photocopying services & $\mathrm{X}$ & $\mathrm{X}$ \\
12 & Printing services & $\sqrt{ }$ & $\mathrm{X}$ & $\mathrm{X}$ \\
13 & Translational services & $\mathrm{X}$ & $\mathrm{X}$ & $\sqrt{ }$ \\
14 & Inter library loan services, & $\mathrm{X}$ & $\mathrm{X}$ & $\sqrt{ }$ \\
15 & Manual Selective Dissemination of Information & $\mathrm{X}$ & $\sqrt{ }$ & $\mathrm{X}$ \\
16 & Book reservation services & $\mathrm{X}$ & $\sqrt{ }$ & $\mathrm{X}$ \\
17 & Library orientation/user education & $\mathrm{X}$ & $\sqrt{ }$ & $\mathrm{X}$ \\
18 & Literature search & $\mathrm{X}$ & $\sqrt{ }$ & $\mathrm{X}$ \\
19 & Sale of old stocks/weeded materials & $\mathrm{X}$ & $\mathrm{X}$ & $\sqrt{ }$ \\
20 & Hiring of library space & $\mathrm{X}$ & $\mathrm{X}$ & $\sqrt{ }$ \\
21 & Consultancy services & $\sqrt{ }$ & $\mathrm{X}$ & $\mathrm{X}$ \\
22 & Registration of users & $\sqrt{ }$ & $\mathrm{X}$ & $\mathrm{X}$ \\
23 & Clearance of students & $\mathrm{X}$ & $\sqrt{ }$ & $\mathrm{X}$ \\
\hline
\end{tabular}

Source: Researchers' Field Survey, 2019

The table above presents the nature of library services provided in MOUAU. There are twenty-three (23) items covering most of the perceived library services. Result shows that six (6) of the services are fee-based. They include: Internet browsing, binding, photocopying, printing, consultancy services, and registration of users. Furthermore, the result shows that nine (9) out of the total number of library services investigated are provided on free-based status. These services on free-based range from manual current awareness services, indexing, charging and discharging, compilation of bibliographies/reading list, manual selective 
Effects of Fee-Based Services on Library Service Delivery in Federal University Libraries in

Nigeria: A Study of Michael Okpara University of Agriculture, Umudike, Abia State, Nigeria

dissemination of information, book reservation, library orientation/user education, literature search, to, clearance of students. Consequently, data generated shows that eight (8) services are not provided by the library. They include e-Selective Dissemination of Information, mobile phone services, e-Current awareness service, abstracting services, translational services, inter-library loan services, sale of old stocks/weeded materials, and hiring of library space.

The implication of this finding is that the library provides mainly free-based services and less of fee-based services. It could also be deduced from the findings that most fundamental services are not being provided by the library. Some of these services such as the hiring of library space, and other ICT-driven library services, if provided on fee-based may have a positive effect on the library. The result of this study which revealed the absence of some services and provision of more of free-based services is in line with the work of Okeke, Urhiewhu and Nwafor (2015) which revealed that fee-based services were already in existence in all three (3) university libraries studied, though at low level. However, this negative attitude or poor application of fee-based services in MOUAU Library could be related to situations like inadequate knowledge of the services by the librarians, managerial attitudes of the parent institution, the attitude of the users, among others. This study partially agrees with the work of Igbokwe, Ezeji and Obidike (2010), which revealed that the major fee-based services were binding and photocopy, while the free services were compilation of bibliography and retrospective services based on the fact that the library charges for registration of users, consultancy services and Internet browsing.

Table 3: Effects of Fee-Based Library Services on MOUAU Library

\begin{tabular}{llcccccc}
\hline S/n & \multicolumn{1}{c}{ Item Statements } & SA & A & D & SD & Mean & Remark \\
\hline $\mathbf{2 4}$ & It enables the library to generate additional income & 36 & 15 & 0 & 4 & 3.51 & Agreed \\
$\mathbf{2 5}$ & It serves as a means of increasing library services & 24 & 23 & 4 & 4 & 3.22 & Agreed \\
$\mathbf{2 6}$ & It increases library patronage & 35 & 4 & 16 & 0 & 3.35 & Agreed \\
$\mathbf{2 7}$ & It increases library's goodwill & 32 & 23 & 0 & 0 & 3.58 & Agreed \\
$\mathbf{2 8}$ & $\begin{array}{l}\text { It enables the library to be self-sufficient and } \\
\text { carryout projects independently }\end{array}$ & 33 & 18 & 4 & 0 & 3.53 & Agreed \\
$\mathbf{2 9}$ & & & & & & \\
& It brings about delivery of quality services in the & 31 & 16 & 0 & 8 & 3.27 & Agreed \\
& library & & & & & & \\
\hline & Grand & & & $\mathbf{3 . 4 1}$ & Agreed \\
\hline
\end{tabular}

Source: Researchers' Field Survey, 2019

Table 3 above presents result on the effects of fee-based services in MOUAU Library. From the few fee-based library services adopted by the library, majority of the respondents believed they have great and positive effects on the overall functioning/ services delivery of the library. This could be seen in the table where all the six (6) perceived effects being investigated obtained mean scores above the criterion mean and received an agreement remark each. These effects as strongly agreed and accepted by majority of the respondents include: it enables the library to acquire additional income (3.51); it serves as a means of increasing library services (3.22); it increase library patronage (3.35); it increases library's goodwill (3.58), it enables the library to be self-sufficient and carryout projects independently (3.53); and it brings about delivery of quality services in the library (3.27). The grand mean is 3.41. From this result, fee-based services have numerous positive effects on service delivery in MOUAU. This agrees with the survey of Igbokwe, Ezeji and Obidike (2010), which shows numerous effects of fee-based services such as increased patronage and productivity on the side of the library. It also agrees with the work of Igyuve and Ashaver (as cited in Ishola, 
2014), which revealed that fee-based have positively impacted on university libraries different areas of services and operations.

Table 4 Challenges Facing Fee-Based Library Services in MOUAU Library

\begin{tabular}{|c|c|c|c|c|c|c|c|}
\hline $\mathbf{S} / \mathbf{n}$ & Item Statements & $\mathbf{S A}$ & $\mathbf{A}$ & $\mathbf{D}$ & SD & Mean & Remark \\
\hline 30 & Poor planning/pricing policy & 12 & 31 & 4 & 8 & 2.85 & Agreed \\
\hline 31 & Absence of quality services in the library & 24 & 27 & 4 & 0 & 3.36 & Agreed \\
\hline 32 & $\begin{array}{l}\text { Gross resistance to the concept of fee-based } \\
\text { services in libraries }\end{array}$ & 36 & 15 & 0 & 4 & 3.51 & Agreed \\
\hline 33 & High costs of fee-based library services & 16 & 35 & 0 & 4 & 3.15 & Agreed \\
\hline 34 & Poor infrastructural facilities in the library & 16 & 39 & 0 & 0 & 3.29 & Agreed \\
\hline 35 & User dissatisfaction & 15 & 32 & 8 & 0 & 2.98 & Agreed \\
\hline 36 & $\begin{array}{l}\text { Inadequate expertise and skills for marketing } \\
\text { library products and services }\end{array}$ & 27 & 24 & 4 & 0 & 3.42 & Agreed \\
\hline \multirow[t]{2}{*}{37} & $\begin{array}{l}\text { Negative users perceptions of fee-based } \\
\text { services }\end{array}$ & 36 & 19 & 0 & 0 & 3.65 & Agreed \\
\hline & Grand & & & & & 3.27 & Agreed \\
\hline
\end{tabular}

Source: Researchers' Field Survey, 2019

The Table above presents data generated on the challenges facing fee-based library services in MOUAU Library. There are eight (8) perceived challenges. The result shows the agreement of all the options by majority of the respondents as among the challenges facing fee-based services. This is so, because all the options had mean scores above the criterion mean of 2.50. These challenges as shown in the table are poor planning/pricing policy (2.85); absence of quality services in libraries (3.36); gross resistance to the concept of fee based services in libraries (3.51); high costs of fee-based library services (3.15); poor infrastructural facilities in the library (3.29); user dissatisfaction (2.98); inadequate expertise and skills for marketing library products and services (3.42); and negative users perceptions of fee-based services (3.65). This shows that fee-based services are faced with lots of challenges in MOUAU Library, as majority of the respondents accepted the items, with grand mean of 3.27.

Based on the acceptance that fee-based services in MOUAU Library are faced with numerous challenges, the present study supports the work of Okeke, Urhiewhu and Nwafor (2015), which reported that there is no fee-based library service policy on ground in the three (3) university libraries studied, which in turn resulted in half-hazard organisational management of fee-based services in the libraries.

Table 5: Strategies to Enhance Fee-Based Library Services in MOUAU Library

\begin{tabular}{llrrrrrc}
\hline S/n & \multicolumn{1}{c}{ Item Statement } & SA & A & D & SD & Mean & Remark \\
\hline 38 & Adequate planning and formulation of policies & 27 & 24 & 4 & 0 & 3.42 & Agreed \\
39 & Development of new technologies & 31 & 20 & 0 & 4 & 3.42 & Agreed \\
40 & Provision of quality services & 11 & 44 & 0 & 0 & 3.20 & Agreed \\
41 & Reduction in the cost of library services & 11 & 36 & 0 & 8 & 2.91 & Agreed \\
42 & Creating awareness on library fee-based services & 24 & 27 & 4 & 0 & 3.36 & Agreed \\
43 & Equipping the librarians with marketing skills & 15 & 32 & 8 & 0 & 2.98 & Agreed \\
44 & $\begin{array}{l}\text { Advocating for management support to embark } \\
\text { on fee-based services }\end{array}$ & 0 & 8 & 43 & 4 & 2.07 & Disagreed \\
45 & $\begin{array}{l}\text { Ensuring attractive library environment } \\
46\end{array}$ & 33 & 18 & 4 & 0 & 3.53 & Agreed \\
& $\begin{array}{l}\text { Creating room for users' feedback on their level } \\
\text { of satisfaction }\end{array}$ & 12 & 31 & 4 & 8 & 2.85 & Agreed \\
\hline & $\quad$ Grand & & & & & & \\
\hline
\end{tabular}

Source: Researchers' Field Survey, 2019 
The Table above presents result on the strategies to enhance fee-based services in MOUAU Library. The table shows the acceptance of majority of the options by the respondents as the strategies. Data shows that the table is made up of nine (9) item statements which represent the perceived strategies to enhance fee-based library services in MOUAU. Majority of the respondents agreed with eight (8) item statements and disagreed with only one (1) statement. The strategies agreed by the respondents include: adequate planning and formulation of policies (3.42); development of new technologies (3.42); provision of quality services (3.20); reduction in the cost of library services (2.91); creating awareness on library fee-based services (3.36); equipping the librarians with marketing skills (2.98), ensuring attractive library environment (3.53), and creating room for users' feedback on their level of satisfaction (2.85). Furthermore, majority of the respondents disagreed with the fact that advocating for management support to embark on fee-based services (2.07) is a strategy to enhance fee-based services in MOUAU Library. The findings revealed numerous strategies to enhance fee-based services in MOUAU Library with a grand mean of 3.05. With these findings, this study adds to the previous work and recommendations of Ahenkorah-Marfo and Osei-Boadu (2013), which recommended that public universities should take advantage of this potentially viable means of income generation and push for a paradigm shift through their library committees.

\section{SUMMARY AND CONCLUSION}

This study critically looked into the effects of fee-based services on library service delivery in federal university libraries, with a focus on the Michael Okpara University Library, Umudike. It is imperative to understand in summary that although numerous literature hold the view that fee-based library services are of great and positive effect on the library, the library of MOUAU is yet to fully tap into these benefits, which fee-based can offer to the totality of service delivery in the university library. This is because the study has revealed that fee-based services in MOUAU Library are still at their low stage, as the library adopts only few of the numerous perceived fee-based services. Based on the findings, it could be right to say that MOUAU Library is among the university libraries that highly depend on their parent institution for the survival of their resources and services. Thus, without the subvention from the parent institutions, these libraries are as good as dead. However, fee-based services should be seen by university libraries as those decisions taken by the library to make provision for certain library needs, which ordinarily they cannot wait for the protocol involved in budget passage and approval in the parent institution before executing them. It could also be seen as an avenue to augment the budgetary allocation received by the library, which is usually insufficient.

Furthermore, there are numerous benefits and positive effects associated with fee-based library services. Not only do these services add to the revenue of the library, it goes a long way in attracting philanthropists to the library thereby drawing patronage, goodwill and projecting the good image of the library. It could be understood that the prices of the library products and services are not exorbitant in the sense that libraries are not profit-making bodies but service-oriented compared to those similar services offered by cyber cafes and other information outlets. With the delivery of relevant and needed services to the clients on an affordable rate, the users would be attracted to the library and also motivated to invest more on the library. Worthy of note are the challenges facing the adoption of fee-based services in the library. These challenges, which manifest in the university management strict monitoring, absence of policy framework and users enlightenment, fraudulent activities of heads of university libraries and inadequate knowledge of the usefulness of fee-based on the side of the librarians and library staff could be the reason why the university libraries especially, 
MOUAU Library has not fully embarked on adoption of fee-based services. It is obvious that if these challenges are not properly handled, there may be complete exploitation and rejection on the side of the library and the users in general. However, some strategies could be adopted to ensure the effectiveness of this system of library services delivery. These strategies would help libraries that have existing fee-based services in the areas of improvement and sustenance, while assisting libraries that wish to adopt the system, to have the right footing. Based on the findings, the study therefore concludes that fee-based library services have great and positive effect on the delivery of library services in federal university libraries.

\section{RECOMMENDATIONS}

The following recommendations are made towards an effective and efficient fee-based library services in federal university libraries:

- Federal university libraries and other libraries should make effort to adopt fee-based services at affordable prices, as means of generating additional income and avoid the overdependence on the parent institution for all financial matters and execution of all projects.

- Federal university libraries should strive to build a good relationship between them (the library), the parent institutions and the users. This will engender management support for these fee-based services with little or no monitoring on the proceeds from these services, while the users tend to patronize these fee-based services. With these, the effort to carry out such services would not be in vain but would yield the required results.

- Federal university libraries should make the provision of relevant services that can be feebased a priority so as to generate additional income for running the library, and thereby augment the slim budgetary allocation given to the libraries.

- It could be seen that digitization, apart from enhancing library services, can also be used as fee-based services and as means of generating additional income. Therefore, management of federal university libraries should incorporate this process to their system and further strengthen it by providing necessary facilities and assistance that would ensure its effectiveness and continuity, including Internet browsing.

- Federal university libraries should be given financial autonomy in developing ways through which they can add to the little subvention given to them by the parent institution/body. This financial autonomy may be seen in the area of allowing the library register its users and the library registration fee proceeds being used for development and sustenance of library services, programmes and projects.

- Heads and management of federal university libraries should engage in lobbying, advocacy, exhibitions and displays among other practices frequently in order to attract the attention of financiers of library projects and programmes and further create awareness on the existing feebased services in the library.

- The library should establish programs to highlight library spaces, which could be rented at a fee. This would not only generate revenue for the library upon hiring but would also project the image of the library to its teaming user community.

- Management of federal university libraries should devise means of equipping the librarians with marketing skills that would enable them market these fee-based services effectively.

- Federal university libraries and other libraries should see the fee-based system as an avenue that would enable the library execute certain projects and should wholeheartedly adopt it and provide policies guidelines to regulate the issue of fee-based services in libraries.

- Management of federal university libraries should develop strategies to overcome dependency on budgetary allocation. This could be done through the provision of fee-based services such as indexing and abstracting services, photocopying services, translation services, binding services, ICT-based services, among others. 
Effects of Fee-Based Services on Library Service Delivery in Federal University Libraries in

Nigeria: A Study of Michael Okpara University of Agriculture, Umudike, Abia State, Nigeria

\section{REFERENCES}

[1] Ahenkorah-Marfo, M. \& Osei-Boadu, R. (2013). Fee-based services as a source of funding for public university libraries in Ghana- A survey. Library Philosophy and Practice (e-journal). 958, 1-15. Retrieved from http://digitalcommons.unl.edu/libphilprac

[2] Anyaoku, E.N. (2009). Potentials of fee-based library services in Nigeria: With a case report of fee-based services in Medical Library. Information Technologist, 9(1), 12-27.

[3] Anyaoku, E.N. (2012). Responding to change: Fee based library services as panacea for library development in Nigeria. UNIZIK Journal of Research in Library and Information Science, 3(2), 91-102.

[4] Chukwueke, C., Onuoha, J. \& Nnadozie, C. O. (2018). Effect of library services on the educational development of secondary school students in Abia State: A study of Igbere Secondary School Igbere. Library Philosophy and Practice (e-journal), 1-18. Retrieved from https://digitalcommons.unl.edu/libphilprac/1847.

[5] Ekoja, I. (1996). Alternative sources of funding in Nigerian university libraries. Library Management, 17(3), 13-21.

[6] Ifidon, E. I. (2005). Fee-based services, a means of marking library materials more rapidly available to Nigeria university library users. Communicate: Journal of Library and Information Science, (1\&2) 41-52.

[7] Ifidon, S.E. (2012). Libraries: Royal way to elude. A paper delivered at the 50th anniversary of Obafemi Awolowo University held at Obafemi Awolowo University, Ile-Ife on 7th August, 2012.

[8] Igbokwe, J.C., Ezeji, E.C. \& Obidike, N.A. (2010). Problems militating against marketing of library services in selected Nigerian libraries. Journal of Applied Information Science and Technology, 4, 7-12.

[9] Ilo, P.I., Idaerefama, Y.H. \& Fufuri, I. (2016). Fee-based library services in Nigerian public libraries: A case study of Rivers State Public Library. Jewel Journal of Librarianship, 9, 107-111.

[10] Ishola, B. C. (2014). Funding problems in Nigerian university libraries: Fee-based library and information services to the rescue, focus on pricing policy. Library Philosophy and Practice (e-journal). Paper 1176. URL: http://digitalcommons.unl.edu/libphilprac/1176

[11] Jenda, C. (2000). Fee based services: A SPEC kit. Retrieved fromhttp:/www.arl.org/bmdoc/spec259web.pdf.

[12] Mahmood, K.H \& Haider, S.J. (2005). Potential for fee-based library services in Pakistan: The Bottom Line: Managing Library Finances, 18(4), 172-179.

[13] Nnadozie, C.O. (2013). Alternative funding models for Nigerian academic libraries. Library Philosophy and Practice (e-journal). Paper 904. Retrieved from http://digitalcommons.unl.edu/libphilprac/904.

[14] Obodoeze, .F.O. (2007). Dynamics of costing library and information services in academic libraries with focus on an Anambra State. UNIZIK Journal of Research in Library and Information Science, 1(1), 44-54. 
[15] Oguntuase, F.Z., \& Falaiye, Z.M. (2004). Meeting information needs of rural communities through repackaging of information. Nigerian Library and Information Science Review $22(1), 1-12$

[16] Okeke, E.O, Urhiewhu, L.O. \& Nwafor, M.C. (2015). Fee-based library services in private university library: challenges and prospect. Information and Knowledge Management, 5(3), 7-15

[17] Okiy R.B. (2005). Funding Nigerian libraries in the 21 st century: Will funding from alternative sources suffice? The Bottom Line: Managing Library Finances, 18(2), 71-77.

[18] Olurotimi, O.S. (2014). Alternative funding of academic libraries in Nigeria: Case studies of Hezekiah Oluwasanmi Library, Obafemi Awolowo University (OAU), Ile Ife and Wesley University of Science and Technology, Ondo (WUSTO) Library. Standard Journal of Educational Research and Essay, 2(6), 200-207. Available online at http://standresjournals.org/journals/SJERE/index.html

[19] Ubogu, J.O. \& Okiy, R.B. (2011). Sources of funds in academic libraries in Delta State, Nigeria. Library Philosophy and Practice.

[20] Ward, S.M., Fong, Y.S. \& Camille, D. (2002). Library fee-based information services: financial considerations. The Bottom Line: Management Finances Journal, 15(1), 22-43.

[21] Yetunde, Z.A. (2008). A study of internally generated revenue (IGR) by university libraries in Nigeria. Borno Library, Archival and Information Science Journal, 7(1), 1-14. 